\title{
POLICY NETWORK IN THE IMPLEMENTATION OF SCHOOL-BASED QUALITY IMPROVEMENT MANAGEMENT POLICIES IN STATE BASIC SCHOOL OF KOTA BANDUNG
}

\author{
Ine Mariane \\ Public Administration Study Program of FISIP UNPAS \\ Ine.mariane@unpas.ac.id
}

\begin{abstract}
This study at the Bandung City Primary School. The problems faced by the effectiveness of the Policy Network based on implementing organizations, policy objectives, policies, and policy environment in the Implementation of School-Based Quality Improvement Management Policies (MPMBS) in Bandung City Primary Schools (SDN). The concept used in this study is about the Smith's policy network.Interaction among actors in the network that will determine how policies should be implemented as the core of the network govern that focuses on interorganizational networks. This policy is used to analyze policies; implementing organizations, policy objectives, policies and policy environment. This study uses a qualitative approach with case study methods, it is based on the focus of research studies that require researchers to explore various aspects of MPMBS in Bandung based on the perceptions and experiences of informants through in-depth interviews, observation participants, and data triangulation. The informants in this study were the Head of the Education Office, the Head of the Curriculum Section of the Education Office, the Education Council and the School Supervisor, the SDN Principal, Teachers in the Curriculum and Student Affairs, School Committees, and Companies in the City of Bandung. The results showed that the policy network in the implementation of the MPMBS policy in Bandung City Elementary School has not been effective, because of the implementation of organizational factors in this case the Bandung City Education Office has not fully carried out its duties, responsibilities and responsibilities in the implementation of the MPMBS policy. As a policy target, the principal has not acted as an innovative and creative leader, the school board has not fully directed, provided input, and monitored the implementation, the school committee also has not acted as an advisor, supporter, controller and mediator for schools. Likewise from environmental factors, Public Elementary Schools in Bandung City have been able to explore the potential, aspirations and community participation of the business world. Research findings, policy networks in the implementation of MPMBS policy must be synergized between government, society and the private sector by building trust, commitment, rules, innovative leadership by managing existing resources and paying attention to the value of the system that applies to the public interest and equal opportunities.
\end{abstract}

Keywords: policy network, MPMBS, participation, commitment, public interest

\section{Introduction}

The National Education Strategic Policy based on Law No. 20 of 2003 includes management of school-based quality improvement (MPMBS) as a management model that provides greater autonomy to schools participatory decision-making that directly involves all school residents (teachers, students, principals employees, parents, and community) to improve school quality, which aims to improve efficiency through flexibility to manage resources, community participation, and simplification of the bureaucracy, quality improvement through parental participation in schools, flexibility in school and classroom management, 
incentive systems and incentives, increasing equity through participation in certain groups, especially the poor, and increasing relevance through flexibility and flexibility in schools to develop school curricula according to environmental needs.

Nanang Fatah Research (2003), Sri Sadiman (2005), Susanto (2009), Heri (2010) and Dwi Setianingsih (2012) and Sari Febriana (2012) discussed the implementation of MPMBS which is a management of school-based education quality improvement seen from evaluation, constraints and the extent of the role of the government, community and private sector in implementing the MPMBS policy. While research conducted by researchers saw the implementation of MPMBS policy in terms of its policy network.

This research that has not improved, because the first education development strategy has been more input oriented so far; second, education development currently is on providing educational input factors; thirdly, currently education faces challenges in education by the region, as reported in http: //www.pikiran peoples.com (03/2004).

Based on the results of the field study, it was found that the problem of education quality in the city of Bandung was still low, as seen from:

1. Public elementary schools in the city of Bandung still depend on the operational costs of education provided by the government.

2. The new city of Bandung has socialized the policy on the Preparation, Use and Reporting of School Budget and Action Plans (RKAS), so there is no uniformity for RKAS posts between one school and another school.

3. There is no firmness in giving sanctions to violators so that they do not cause deterrent effects on the perpetrators.
4. There is no cohesiveness of performance between officials of the Bandung City Education Office.

5. Slow in the recruitment and periodization of the principal's tenure, so that there are several school principals who have expired their terms of office late.

6. The Education Office imposes fees on schools when holding an activity.

Based on the above problems, the implementation of MPMBS policies in Bandung's public elementary schools in the city encountered several obstacles, including: (1) the MPMBS policy has not been fully and correctly understood by stakeholders; (2) resistance to change due to interests, technical and managerial incapacity (3) the difficulties in implementing MPMBS policies (independence, cooperation, participation, openness and accountability) (4) the participation of school stakeholders is not optimal, and (5) notes yet compact optimum teamwork in implementing MPMBS.

The purpose of this study which is considered ineffective, what is the problem, is that there are several solutions and actions that must be implemented. Bandung increases.

The policy network model is aimed at building stakeholders as networks in every public policy, especially at the policy implementation stage, thus experiencing rapid development with the growth of clusters and quango organizations as a result of the interaction between the government, the private sector and the community.

This research is expected to improve the quality of education by helping the teaching and learning process in schools, especially in meeting the needs of school facilities and infrastructure in the city of Bandung by forming a policy 
network in the implementation of MPMBS policy.

\section{Method}

This study uses a qualitative approach that explains that the research procedure produces descriptive data in the form of written or verbal words from people and observable behavior. A qualitative approach is used because it is a formulation of symptoms, information or information about the policy network in Bandung City State Elementary
School is done through a study of the situation and conditions and the system of ideas of perpetrators involved in it. Thus in this study, researchers want to describe a reality in public administration, namely the Policy Network in Implementing School-Based Quality Improvement Management Policies (MPMBS) in Bandung City State Elementary School. A qualitative approach which is formed based on informant views.

The selection of qualitative techniques can be seen in the following table:

Table 1.

Qualitative Research Steps

\begin{tabular}{ll}
\hline No & \multicolumn{1}{c}{$\begin{array}{c}\text { Qualitative research } \\
\text { according to Creswell }\end{array}$} \\
\hline 1 & $\begin{array}{l}\text { Qualitative research occurs in } \\
\text { natural settings in the form of } \\
\text { behavior and events (Creswell, } \\
\text { 2009: 195) }\end{array}$
\end{tabular}

Steps taken

Natural setting in this study is the determination of policy networks in the implementation of MPMBS in Bandung City Elementary School. The process of policy networks in im plementasi MPMBS policy seen from implementing organizations, policy objectives, policy and environmental MPMBS. The behavior observed in this study is the behavior of the parties involved in the policy network in the im $p$ lementasi MPMBS policy

2 The placement of theory in qualitative research can be in various ways, namely the theory at the beginning of the research, or the theory at the end of the study. Theory may appear at the beginning and be modified or adjusted based on the views of the informant. This model is not being tested, but modified. At the end of the study, researchers proposed a modification model. The theory used at the beginning serves as an explanation for behavior and attitudes and may be complete with variables, constructs and hypotheses. Although researchers may not refer to 


\begin{tabular}{|c|c|c|}
\hline No & $\begin{array}{l}\text { Qualitative research } \\
\text { according to Creswell }\end{array}$ & Steps taken \\
\hline & $\begin{array}{l}\text { them as theories, the theory } \\
\text { provides a broad } \\
\text { explanation. So that in } \\
\text { qualitative research } \\
\text { researchers do not position the } \\
\text { theory in a central position } \\
\text { when designing research and } \\
\text { interpreting } \\
\text { placement of theory in } \\
\text { qualitative research is used as } \\
\text { a guideline for verification and } \\
\text { analysis when in the field } \\
\text { (Creswell, 2009: 65) }\end{array}$ & \\
\hline 3 & $\begin{array}{l}\text { Researchers are instruments in } \\
\text { collecting data (Creswell, } \\
\text { 2009: 195) }\end{array}$ & $\begin{array}{l}\text { Researchers are instruments incollecting data, so } \\
\text { that inqualitative research choose informants as } \\
\text { data sources and conduct data collection } \\
\text { (observation, interviews, looking for secondary } \\
\text { data) where the next step is data analysis and } \\
\text { conclusions. }\end{array}$ \\
\hline 4 & $\begin{array}{l}\text { Data obtained from qualitative } \\
\text { research is descriptive, in the } \\
\text { form of words or pictures } \\
\text { (Creswell, 2009: 195) }\end{array}$ & $\begin{array}{l}\text { Data obtained from qualitative research in the } \\
\text { form of interviews with information, which were } \\
\text { recorded and processed into words (interview } \\
\text { transcripts). Events are recorded in the form of } \\
\text { images. In addition there are also secondary data } \\
\text { in processing research }\end{array}$ \\
\hline 5 & $\begin{array}{l}\text { Individuals develop a } \\
\text { sense (meaning) of their } \\
\text { subjective experience. This } \\
\text { meaning varies and encourages } \\
\text { researchers to find complex } \\
\text { views (Creswell, 2009: 8). The } \\
\text { focus of the research is the } \\
\text { perception and experience of } \\
\text { informants, and the way they } \\
\text { understand their lives. } \\
\text { (Creswell, 2009: 195) }\end{array}$ & $\begin{array}{l}\text { The data obtained from the study are the results } \\
\text { of interviews with informants. NP } \\
\text { remises adjusted informant networks implementasi } \\
\text { experience in policy } \\
\text { MPMBS policy. So in this research is the } \\
\text { informants Bandung City Education } \\
\text { Department, Principals and Teachers Field of } \\
\text { curriculum, the School Committee and the } \\
\text { Board of Education as well as the Company - } \\
\text { Company directly involved in the policy } \\
\text { network in the im plementasi MPMBS policy. } \\
\text { To be able to understand the perceptions of } \\
\text { informants, interviews were used that } \\
\text { wereopen-ended. Questions were asked to find } \\
\text { out the views and experiences of informants. }\end{array}$ \\
\hline 6 & $\begin{array}{l}\text { Qualitative focus on processes } \\
\text { that occur as a product } \\
\text { or outcome (Creswell, 2009: } \\
\text { 195) }\end{array}$ & $\begin{array}{l}\text { The process observed } \\
\text { in this study is the policy network in the } \\
\text { implementasi MPMBS policy. This is } \\
\text { based right on the phenomenon that exists is not } \\
\text { yet } \\
\text { effective implementation of the policy network } \\
\text { in the imp lementasi MPMBS policy. So } \\
\text { researchers are interested in doing research in }\end{array}$ \\
\hline
\end{tabular}




\begin{tabular}{lll}
\hline No & \multicolumn{2}{c}{ Qualitative research } \\
according to Creswell & \multicolumn{3}{c}{ Steps taken } \\
\hline & \multicolumn{1}{c}{ understanding how the process occurs. } \\
\hline 7 & The main concern in & This study takes the object of study in \\
qualitative research is data that & S ekolah Dasar \\
occurs in certain cases, so & (SDN)in Bandung, the western regions are taken \\
there is no need to make & SD N 58 Pajag alan, northern region, taken SDN \\
generalizations & (Creswell, & Sukarasa 3, east taken SDNMargahayu Block I \\
2009: 195) & and territories Bandung being taken \\
& SDN Karangpawulang, in South \\
& B andung area, SDN Merdeka 5 was taken . \\
\hline
\end{tabular}

This approach is used to build understanding and provide an

\section{Result and Discusion}

The results of the discussion, the MPMBS policy in Bandung City State Elementary School, namely the Education Office, School Principals, School Committee, Education and Supervisory Board, MPMBS policy, and school environment showed that participation from the target group could be classified into contribution variables namely loading facilities, personnel and funds.

From the network model that is formed, there are mediators, namely the School Committee and the Education Council, which plays a role in giving pressure to the government by forming changes in the sub-system of policy, so that there is a change in objectives towards better public interest, and (transactional) policy with regard to rules, trust, value systems and innovative political identity sources and creative leaders.

Network policy that model is formed in the implementation of Bandung City State Elementary School's MPMBS policy by paying attention to the tensions that occurs at the level of the implementing organization in this case the Bandung City Education Agency, the target of implementing the policy is the Principal and Teacher Field explanation of the phenomenon about the process.

curriculum and environment both internal environment namely the School Committee and the Education Council, as well as the external environment, private companies that have a responsibility for the welfare of the surrounding community.

On the other hand there are also forms of non-physical participation in the form of thought and organizational participation, in the form of meetings and the delivery of aspirations from the community to the Office of Education as executor, in relations to physical participation, the Government in this case the Bandung City Education Office is required to always adjust to the development of the environment as an effort to respond to global developments. These environmental developments include internally and externally. Internal changes include the complexity of the workload of public organizations. The demand factors for public organizations become more flexible in the administration of government.

Policy networks in the implementation of MPMBS policy with the foundation of government, society and the private sector must be able to make use of breakthroughs or innovations in realizing facilities and infrastructure in order to improve the quality of school 
education with the MPMBS concept built on trust between the government, the community and the private sector so that they can grow commitments that are based on clear rules and value systems for the public interest by innovative leaders so that they can explore the resources they have to produce equal opportunities for all levels of society.

Trust or trust is important, because it can help regulate complexity, help develop capacity for action, increase collaboration and improve organizational learning skills. A very important key in building high trust in acting with integrity, and demonstrating attention. Increasing the level of trust is mentioned above, even though there are conflicts between parties in the organization.

Commitment is a promise to ourselves or to others reflected in our actions, or an attitude that reflects the extent to which an individual knows and is bound to his organization.

The resources that are owned are one of the most important factors that cannot even be released from an organization, both government and company, as determined by the development of an organization because of human resources employed in organizations as movers, thinkers and planners to achieve organizational goals, resources in the form of material, money, methods, tools and markets.

The school environment is a resource that can be relied upon to form MPMBS policy implementation networks, consisting of internal and external environments where there is a value system that is considered good. which is not well, what is ethical and what is unethical is what is known as the norm.
Equitable education in the sense of equal opportunity to get the problem that has received attention, especially the growing awareness that education has an important role in nation building, along with the development of democratization of education with the slogan education for all. Reform and revitalization of roles organizations are carried out internally in an organization to increase professionalism. Metamorphosis of public organizations in responding to internal and external demands is realized in the form of reform, revitalization and formation of government networks as part of the new public governance paradigm, by striving for implementation of public services as a regulator function; privatization is carried out so that public services are carried out by the government, the community and the private sector can be maximized through policy networks .

Equitable education includes two important aspects, namely equality and equity. Equality or equality means equal opportunity to get education, while equity means fairness in obtaining equal educational opportunities among various groups in society. Access to equal education means that all school-age residents have had educational opportunities, while between groups can enjoy education equally. Conceptually the concepts of equalization are: active equity and passive equity. Passive equity is equalization which emphasizes more on equality of getting the opportunity to enroll in school, while active equity means similarities in providing opportunities for students to obtain the highest learning outcomes.

In this understanding education equity has a broad meaning, not only equality in obtaining educational opportunities, but also having students be treated equally in their potential to be able to manifest optimally. If these dimensions 
form the basis for the problem of educational equity, it seems how complicated and difficult it is to assess the education appearing to be still dominant both in terms of quantity and effectiveness.

An innovative leader is needed in the formation of the MPMBS policy network, first from a clear, measurable vision and an open goal for innovation. An innovative leader is not easily satisfied with the results obtained and is always eager to do better, not too fixated on the rules and can do a little 'improvisation'. looking for alternatives, doing the work as effectively as possible; and the second in a new way will be ready to face failure, always testing innovation first and see results and always excited.

The findings from the study to improve the quality of education in Bandung City State Elementary School required for an openness between the levels of the policy subsystem and the role of intermediaries as the center of the network that can be described as a spider network whose success is influenced by elements of trust, commitment, resources, rules, value systems, innovative leaders, public interests and equal opportunities in the city of Bandung. More clearly, the policy network model in the implementation of the MPMBS policy is formed :

Table 2.

Network Model

\begin{tabular}{|c|c|}
\hline Existing Network Model (Smith, 1977) & Spider Network Model (Findings) \\
\hline $\begin{array}{l}\text { In an ideal policy network there will be } \\
\text { interaction and reaction from implementing } \\
\text { organizations, target groups and } \\
\text { environmental factors that result in a } \\
\text { somewhat heated atmosphere (tensional) } \\
\text { and then followed by } \\
\text { a bargaining action(transaction). which } \\
\text { produces feedback forpolicy } \\
\text { makers and can be used as inpu in the } \\
\text { subsequent policy formulation. }\end{array}$ & $\begin{array}{l}\text { A spider policy ejaring has the } \\
\text { characteristic role of mediator in charge of } \\
\text { driving the interests of a number of public, } \\
\text { private and community institutions to } \\
\text { alllevels of government so that has a } \\
\text { number of basic beliefs that are used to } \\
\text { compile regulations, budgets and resources } \\
\text { that are owned so as to achieve the desired } \\
\text { goals in accordance with the public } \\
\text { interest. }\end{array}$ \\
\hline $\begin{array}{l}\text { There are four variables that must be } \\
\text { examined in reviewing the implementation } \\
\text { of public policy, namely: } \\
\text { 1. Implementing organization } \\
\text { 2. Target group } \\
\text { 3. the policy } \\
\text { 4. Policy environment }\end{array}$ & $\begin{array}{l}\text { To establish an effective network needs to } \\
\text { pay attention unsur_unsurements: } \\
\text { 1. High trust between government, } \\
\text { community and parties } \\
\text { 2. Commitment among actors 3. Digging } \\
\text { up resources } \\
\text { 4. Pay attention to the value system applies } \\
\text { in the community } \\
\text { 5. Rules that apply to the network } \\
\text { 6. Innovative leadership } \\
\text { 7. Equalization of opportunities } \\
\text { 8. Pe fulfillment of public interest }\end{array}$ \\
\hline
\end{tabular}

The policy network model in the implementation of school-based quality quality management policies in Bandung
City State Primary Schools is comprehensive from the development of the paradigm of state administration 
science to new public governance. As the most recent discourse of state administration. The paradigm of state administration has undergone developments from old public administration, new public management, new public services, and new public governance.

The concept of a policy network for the implementation of the MPMBS policy is a new policy that is expected with the decentralization paradigm in government that is expected that the implementation of MPMBS can truly improve the quality of education. One strategy is to create conditional conditions to be able to implement MPMBS, namely: Capacity building and commitment of all school residents, including the community and parents of students. Efforts to strengthen the role of the principal must be the policy that accompanies the implementation of the MPMBS policy.

The MPMBS policy network builds a democratic, transparent and accountable school culture, including familiarizing schools to make accountability reports to the public. The model displaying the School Budget on the school notice board conducted by Managing Basic Education (MBE) is a very positive initial stage. Also make incidental reports in the form of booklets, leaflets, or posters about the planned school activities. How harmonious if the headmaster and chair of the School Committee can perform together in the media.

In terms of policy networks in the implementation of the MPMBS policy, the central government plays a role in monitoring and evaluation. In words, the central government and local governments need to carry out joint activities in the framework of monitoring and evaluating the implementation of MPMBS in schools, including the implementation of block grants received by schools. Not just doing MPMBS training, which is more fulfilled by giving information to schools. The school empowerment model in the form of mentoring or facilitation is considered to provide MPMBS upgrading.

The inherent values in the new public management paradigm such as efficiency, rationalization, productivity and business conflict, conflict with the values of public interests and democracy. Denhardt and Denhardt's (2007) opinion because the owner of the public interest is essentially a public (public), then the administrator in running the government must focus on the responsibility of serving citizens. The role of serving citizens is referred to as the new public service paradigm.

The paradigm of new public service requires the involvement of citizens in good governance at the planning level up to policy implementation. Administrators must serve the community responsibly, prioritize ethics and accountability in every program or project aimed at the community within a democratic framework.

In public service focusing on the relationship between policy makers and public organizations. Good governance focuses on disseminating social normative, political, and administrative models of governance by supranational organizations such as the World Bank. New public governance focuses on five principles including: (a) socialpolitical governance, (b) public policy governance, (c) administrative governance, (d) contract governance, (e) network governance. 
First, social-political governance focuses on institutional relations with society. relationships and interactions must be understood to understand the implementation of public policy. Second, public policy governance, focusing on how you are policy makers and network interactions to make and decide on public policy processes. Third, administrative governance focuses on the implementation of the 21 st century public policy. Fourth, contract governance focuses on the delivery of public services as an effort of responsibility in public services. Fifth, network governance focuses on organizing on interorganizational networks. Functions where with or without the government to provide public services.

All the perspectives of governance theory above are important contributions to our understanding of the implementation of public policy and the implementation of public services. The big challenge for the development of state administration is to provide the best formula for providing public policy and providing 21st century public services.

Based on the development theory implemented by the government in the 21 st century, it strives to realize good governance as the concept of good governance. A general understanding of governance or governance hasalized in Indonesia since the 1990s. The concept of being popular in 1996 along with the interaction between the Indonesian government and foreign countries as aid-giving countries which highlighted the objective conditions of Indonesia's economic and political development.

This is often related to the policy of providing assistance from country donors, by making the issue of governance issues one of the aspects considered in the provision of assistance, whether in the form of loans or grants. Building good governance is changing the way the government works, making the government accountable, and building capable actors outside the country to play a role in making a new system that is generally useful. In this context, there is no single development goal that can be realized by changing the characteristics and working on state and government institutions. Efforts to accommodate the diversity of community realities, good governance must be Therefore, building good governance is a large social project. To be realistic, the effort must be done in stages.

The government (the state), civil society (indigenous peoples, civil society, civil society), and the private sectors are the three basic elements that build networks and equal and synergic interaction in the implementation of good and responsible governance that is achieved when the implementation of political authority, economics and administration. Where such interactions and partnerships are usually only developed with the basis of trust, commitment, resources, rules, value systems, innovative leaders, public interests and equal opportunities.

Policy networks in the implementation of MPMBS policies in Bandung City Elementary School must be able to implement network governance principles that focus on how to provide public services organized through interorganizational networks on the basis of trust, commitment, resources, rules, value systems, innovative leaders, public interests and equal opportunities.

With the form of a spider policy network that has a characteristic role of mediator in charge of leading a coalition of public numbers and private 
institutions at all levels. and human resources in order to achieve the desired goals public interest. With the formation of a high trust between the government, the community and the private sector, strong collaboration will be formed based on the existing resources and systems of values and rules that apply in the community and led by an innovative headmaster, there will be equal opportunity to improve quality school which is the fulfillment of the public interest.

\section{Conclusion}

\section{Conclusion}

Based on the results of the study, the author's conclusion is that the policy network in the implementation of MPMBS policy in Band City Elementary School is still not running effectively but has been formed especially in interpretation and application activities, which are seen from: implementing policies, policy objectives, policy and policy environment

Acting policy in this case the Bandung City Education Agency has not played an active role in directing State Primary Schools in Bandung City regarding policies that must be implemented, namely the MPMBS policy, so that there are schools that must be implemented in order to achieve school quality both in accordance with the Minimum Service Standards set in Education Smart

The key to successful policy networks in MPMBS depends heavily on the role of the principal and teacher entrepreuneur. They can identify and solve problems in their own unique ways and collectively collect information and make choices according to the conditions in their schools. The also plays a large role in the School Committee supporting the school program. In addition to parents, the school also has a cooperative relationship with the business world and the industrial world in the implementation of school programs.

Policy networks in the Implementation of MPMBS Policy are achieved through two elements, namely the process and components of effective school management. Judging from the process, MPMBS activities consist of planning, organizing, implementing and supervising. From the point of view of its components, MPMBS consists of management: (1) curriculum and learning, (2) students, (3) educators and education personnel (4) financing, (5) facilities and infrastructure, (6) school and community relations, and (7) school culture and environment.

Concretely, schools must implement a policy network approach in MPMBS according to the environmental conditions, ability of resources, and available facilities.

The policy network in the implementation of MPMBS policy in Bandung City State Elementary School implements the principle of network governance, where the government, society and the business world has a synergy of networks and interactions to implement MPMBS policy by paying attention to elements of trust, commitment, resources, rules, value systems, innovative leaders, public interests and equal opportunities in the city of Bandung.

\section{Recommendations}

1. The Government in this case the Bandung City Education Office must be able to build policy networks and synergic interactions with the community and the business world based on their trust, commitment, resources, rules, value systems, 
innovative leaders, public interests and equal opportunities.

2. We recommend that policy networks in the implementation of MPMBS policies supported by leadership styles of principals who are innovative and creative, have a clear vision and mission so that the objectives of the policy can be achieved effectively.

3. Policy networks in the implementation of MPMBS policy should pay attention to the value of the system that applies in Indonesian society, namely the values of Pancasila as the political identity of the Indonesian Nation.

\section{References}

Cooper, Donald R. and Pamela S. Schlinder. (2008). Business research methods. New York : Mc Graw-Hill.

Creswell, J. W. (2004). Research design: qualitative, quantitative, and mixed methods approaches. London: SAGE Publications.

Denhardt, J. V. \& Robert B. D. (2007). The New public service. New York: ME Sharp.

Fatah, N. (2003). Landasan Manajemen Pendidikan. Bandung : Rosda Karya.

Sri, S. (2011). Public Policy Network: A New Framework for Organizing Governance. Purwoketo:

Diponogoro University.

Republic of Indonesia State Law Number 20 of 2003 concerning the National Education System

http: //www.pikiran peoples.com $(03 / 2004$ 